Journal of Finance and Banking Review

Journal homepage: www.gatrenterprise.com/GATRJournals/index.htm/

J. Bank. Fin. Review 2 (3) $36-41$ (2017)

\title{
Post Financial Crisis and Macroeconomic Fundamentals on Household Debt in Advanced Economies
}

\author{
Siti Aminah Mainal ${ }^{1 *}$, Catherine S F Ho ${ }^{2}$, and Jamaliah Mohd Yusof ${ }^{3}$ \\ ${ }^{1,3}$ Faculty of Business Management, Universiti Teknologi MARA, 42300, Selangor, Malaysia \\ ${ }^{2}$ Arshad Ayub Graduate Business School, Universiti Teknologi MARA, 40450, Selangor, Malaysia
}

\begin{abstract}
Objective - The unwarranted household debt initiated the global financial crisis which led to severe worldwide financial instability. Deleveraging process which has been taking place since the crisis has been slow and there is no quick fix to the debt issue. The lack of study on the effect of financial crisis on household debt justifies the objective to investigate macroeconomic fundamentals and financial crisis on household debt.

Methodology/Technique - This study applies panel data analysis in ten advanced economies from 2001 to 2013 . The random effect (RE) generalized least square estimator is used in the regression to examine macroeconomic factors and post financial crisis period as control variable on household debt.

Findings - Findings confirm that post financial crisis period has significant negative effect on household debt which affirmed the deleveraging process in most advanced economies. Economic growth and household disposable income too have negative relation with household debt. Nonetheless, macroeconomic factors such as inflation, housing price and household consumption encourage household debt in advanced economies.

Novelty - This study suggests that empirical evidence support that household avert from borrowing post financial crisis. Intensification of housing price and other consumption expenditure, if left unrestrained, may elicit another debt crisis. These are challenges faced by policy makers to curb household debt which entail risks for households, the financial system and the wider economy.
\end{abstract}

Type of Paper: Empirical

Keywords: Household Debt; Post Financial Crisis; Macroeconomic Factors.

JEL Classification: G01, G02.

\section{Introduction}

Household debt has grown considerably in most developed countries over the two decades, both in absolute terms and relative to household income. This has raised concern about the sustainability of household debt and the implications for the stability of the financial system if it is not sustainable (Debelle, 2004). Household indebtedness surged in several advanced economies prior to the global financial crisis. The drastic increase in household debt and the meltdown of the U.S subprime mortgage market was the epicenter of the global financial crisis. Following the leverage binge in advanced economies over the three decades preceding 2008, debt growth, particularly household debt is generally likely to be low in the years ahead (Buiter \& Rahbeir,

\footnotetext{
* Paper Info: Received: February 15, 2017

Accepted: June 16, 2017

* Corresponding author:

E-mail: stiaminah844@salam.uitm.edu.my

Affiliation: Faculty of Business Management, Universiti Teknologi MARA.
} 
2012). Nonetheless, while some deleveraging has taken place in a number of countries, the speed of deleveraging varies widely in different countries. Debt levels often remain high, and hence, this study is motivated by the necessity to determine the effects of post financial crisis inclusive of macroeconomic and other factors on household debt burden in ten advanced economies.

\section{Literature Review}

There have been studies on the effects of household debt during pre and post financial crisis base on different methods and different regions. Brown, Haughwout, Lee, and Klaauw (2010) conducted a study in U.S using the Consumer Credit Panel from Q1 1999 to Q1 2010 and found that up to 2008, there was a substantial increase in consumer indebtedness but the figures began to decline subsequently. Tang and Upper (2010) who investigated 20 banking crises around the world, found that financial crises tend to be followed by a protracted period of debt reduction, particularly in the household sector. Magri and Pico (2012) conducted a study of economic and financial crises on household debt in Italy discovered that after years of rapid expansion, credit to Italian household began to slow down in 2007. The deceleration grew in 2008 onwards as banks adopt restrictive standard for loans to households. Buiter and Rahbeir (2012) in a study on selected advanced economies found that household credit growth remained sharply below the growth rates post financial crisis. Theories that are prominent in the literature of household debt are the Keynes consumption theory and lifecycle hypothesis ( $\mathrm{LCH})$. LCH is an economic theory that pertains to spending and saving habits of people over the course of their lifetime. The concept which was developed by Franco Modigliani and Richard Brumberg in 1954 presumes that an individual based his consumption on a constant percentage of an anticipated life income. The $\mathrm{LCH}$ concludes that the average propensity to consume is greater in young individuals since they are borrowing against future incomes and the ageing individuals use their savings. Middle age people, on the other hand, have a greater propensity to save and a lower propensity to consume enhance by a typically higher income. Studies have investigated the empirical validity of Keynes consumption theory and life cycle theories which take into consideration various macroeconomic factors and other factors. There are many studies that relate interest rates as one of the factor that causes a rise in household debt. Previous studies have revealed that low interest rates will cause a rise in household debt and vice versa (Brown \& Taylor, 2008; Crawford \& Faruqui, 2012). Past studies have revealed inflation rate as one of the determinants that affect household debt. Dynan and Kohn (2007) also stated that household debt could increase when inflation rate was lower. A study by Jacobsen and Naug (2004) revealed that when houses were sold at a higher price, household debt would rise. Bloxham and Kent (2009) did a study on household indebtedness in Australia and found negative relationship between unemployment rate and household debt burden. Girouard, Kennedy, and Andre (2007) examined the relationship between consumer durables expenditure and household balance sheet. They advocated that consumer consumptions have a positive relationship with household debt. Past literatures have discussed the role of economic growth in relation to household consumption and household debt. Among the researchers are Townsend and Ueda (2006) who affirmed that over the longer term, greater household financial access is closely associated with economic growth. Contradicting to Mian, Sufi, and Verner (2015) on 30 countries from 1960 to 2012, a recent study by Harari (2017) relate that debt fuelled consumption added to private consumption, and thus GDP growth in the decade prior to 2007, but reduced consumption during and after the financial crisis. Brown and Taylor (2008) in their research had used survey data for Germany (German Socio-economic Panel 2002 wave), Great Britain (British Household Panel Survey 2000 wave) and the USA (Panel Study of Income Dynamics 2001 wave) to determine whether differences existed in the relationship between households' assets and debt across countries. They found that for each country, financial debts were lowest for those households in the bottom total household income quartile. In another study by Crawford and Faruqui (2012) over the past 30 years, Canada had displayed an increasing trend in household debt. Using micro data to focus the main factors underlying the resilient trend since late $1990 \mathrm{~s}$, they found that increase in real household income and low interest rates have resulted in the increase in home ownership rates and hence higher mortgage debt. 


\section{Research Methodology}

\subsection{Data and Estimation}

Historical data of ten advanced economies from 2001 until 2013 are collected from the International Monetary Fund, the World Bank Open Data database and Central Banks. The ten advanced economies examined include United States, United Kingdom, Spain, South Korea, Japan, Italy, Germany, France, Canada and Australia. The data series for each factor and expected relations are shown in Table 1. Post financial crisis is treated as a control variable. The model being estimated in this study is stated as follows:

$$
\begin{aligned}
\mathrm{HDB}_{\text {it }}=\alpha+\beta 1 \mathrm{IR}_{\mathrm{it}}+\beta 2 \mathrm{IF}_{\mathrm{it}}+\beta 3 \mathrm{HPI}_{\mathrm{it}}+\beta 4 \mathrm{UE}_{\mathrm{it}}+\beta 5 \mathrm{HCE}_{\mathrm{it}}+\beta 6 \mathrm{EG}_{\mathrm{it}}+\beta 7 \mathrm{HDY}_{\mathrm{it}}+\beta 8 \mathrm{CCI}_{\mathrm{it}} \\
+\beta 9 \mathrm{DCRISIS}_{\mathrm{it}}+\epsilon_{\mathrm{it}}
\end{aligned}
$$

The variables are transformed through the measure of computing the percentage changes in order to avoid the model from producing spurious regression results. Preliminary analysis also includes the descriptive statistics and correlation test are also conducted on the regressors included in the regression model. The macroeconomic and other factors included in the model were determined by the Levin-Lin Chu (LLC), ImPasaran-Shin (IPS), Augmented Dickey-Fuller (ADF) and Philips Peron-Fisher (PP-Fisher) stationarity tests. The regression analysis is based on the Random Effect (RE) generalized least square method. In addition, a Hausman test was conducted to ascertain whether the Fixed Effect (FE) or the RE was the appropriate model. The summary of variables proxies and expected results are shown in Table 1.

Table 1. Variables and Measurements

\begin{tabular}{|l|l|c|}
\hline \multicolumn{1}{|c|}{ Variable } & \multicolumn{1}{|c|}{ Measurement } & $\begin{array}{c}\text { Expected } \\
\text { Result }\end{array}$ \\
\hline Household Debt Burden (HDB) & Household gross debt to gross disposable income ratio & - \\
\hline Interest Rate (IR) & Annual lending interest rate & - \\
\hline Inflation Rate (IF) & Consumer price index & + \\
\hline Housing Price (HPI) & Housing price index & - \\
\hline Unemployment Rate (UE) & Unemployment rate & + \\
\hline $\begin{array}{l}\text { Household Consumption } \\
\text { Expenditure (HCE) }\end{array}$ & $\begin{array}{l}\text { Household final consumption expenditure annual growth } \\
\text { percentage }\end{array}$ & $+/-$ \\
\hline Economic Growth (EG) & Gross Domestic Product (GDP) annual percentage growth \\
\hline $\begin{array}{l}\text { Household Disposable Income } \\
\text { (HDY) }\end{array}$ & Personal disposable income & + \\
\hline Consumer Confidence (CCI) & Consumer confidence index & + \\
\hline
\end{tabular}

\subsection{Stationary Test}

The results of panel unit-root tests in this study include the Levin-Lin-Chu (LLC), Im-Pasaran-Shin (IPS), Augmented Dickey-Fuller (ADF) and Philips Peron-Fisher (PP-Fisher) tests. The null hypothesis declares the variable has a unit-root and rejecting the null hypothesis shows that the variable has no unit-root and is stationary. The result illustrates the stationary of the data which is indicated by all four (4) tests for each of the variable that reject the null hypothesis when the probability is less than 0.05 (p-value $<0.05$ ). Referring to the results again in Table 2, it was found that almost all variables show stationary result and significantly reject the null hypothesis at 0.01 and 0.05 significant levels for the entire four (4) unit-root tests. 
Table 2. Stationary Tests

\begin{tabular}{|l|l|l|l|l|}
\hline & \multicolumn{1}{|c|}{$\begin{array}{c}\text { LLC } \\
\text { t-stat }\end{array}$} & \multicolumn{1}{c|}{$\begin{array}{c}\text { IPS } \\
\text { W-stat }\end{array}$} & $\begin{array}{c}\text { ADF-Fisher } \\
\text { Chi-square }\end{array}$ & \multicolumn{1}{c|}{$\begin{array}{c}\text { PP-Fisher } \\
\text { Chi-square }\end{array}$} \\
\hline HDB & $-4.7043 * * *$ & $-3.9104 * * *$ & $51.8990 * * *$ & $40.7740 * * *$ \\
\hline IR & $-8.4150 * * *$ & $-5.4761 * * *$ & $64.4785 * * *$ & $62.0752 * * *$ \\
\hline IF & $-9.2000 * * *$ & $-6.0388 * * *$ & $70.3004 * * *$ & $81.4670 * * *$ \\
\hline HPI & $-3.6950 * * *$ & $-2.5444 * * *$ & $45.5379 * * *$ & $34.1062 * *$ \\
\hline UE & $-6.5566 * * *$ & $-3.7751 * * *$ & $47.2329 * * *$ & $51.9830 * * *$ \\
\hline HCE & $-5.8687 * * *$ & $-3.5689 * * *$ & $47.3991 * * *$ & $39.5932 * * *$ \\
\hline EG & $-7.1129 * * *$ & $-4.4218 * * *$ & $54.0374 * * *$ & $60.3175 * * *$ \\
\hline HDY & $-5.6569 * * *$ & $-3.6993 * * *$ & $46.1376 * * *$ & $39.0311 * * *$ \\
\hline CCI & $-11.8759 * * *$ & $-9.0328 * * *$ & $102.848 * * *$ & $174.407 * * *$ \\
\hline
\end{tabular}

Note: $* * *$ and $* *$ denote statistical significance at 1 , and $5 \%$.

\section{Results}

\subsection{Regression Results}

It is important that tests were run to find the best fit model in the panel regressions. Firstly, between Pooled OLS and FEM, the F-Test or Redundant Fixed Effects-Likelihood Ratio was performed. The results of the FTest of the above model revealed $6.1906(\mathrm{p}<0.01)$, meaning that the null hypothesis have to be rejected and FEM is superior. Secondly, between Pooled OLS and REM, the BPLM test was performed and results from the test revealed $41.6481(\mathrm{p}<0.01)$, meaning that the null hypothesis has to be rejected and hence REM is superior. Finally, between FEM and REM, a Hausman test was conducted to choose the best fit model. The result of this test reveals that ( $\mathrm{p}=1)$, meaning that it is not significant. Tests fail to reject the null hypothesis and that means the REM is a better model. With regards to the robustness of the estimates, we computed different types of robust standard error for the panel data models. For GLS weights, since T $>$ N, we apply crosssection weights which allow for heteroscedasticity for cross sectional dimension. As for the coefficient covariance method, we apply the cross-section weights. It was found that before and after the robustness tests, the result for the standard error is more or less the same, meaning that the heteroscedasticity and autocorrelation problem is insignificant. Having accepted REM as the superior model, the result further revealed that (holding all other variables constant) for every $1 \%$ increase in IF, HDB will increase by $0.586 \%$. Meanwhile for every $1 \%$ in HPI, HDB will increase by $0.194 \%$. For HCE, every $1 \%$ increase will cause HDB to increase by $0.0163 \%$. However, for EG, for every $1 \%$ increase will cause HDB to decrease by $0.007 \%$ and the similar result applies to HDY. As for financial crisis, every $1 \%$ increase will cause HDB to decrease by $0.016 \%$. The Variance Inflation Factor (VIF) measures how much the variance of the estimated regression coefficients are inflated as compared to when the predictor variables are not linearly related. VIF is used to describe how much multicollinearity exists in a regression analysis with VIF of more than 5 to 10 indicates high correlation. The VIF results for the model recorded less than 5 , which is within the category of moderately correlated. The test for coefficient validity which is the Wald test in which the test carries the null of each parameter that is $\beta=0$. A rejection of the null hypothesis indicates that the coefficient of the parameter is not zero and the results show that the Wald test is 124.40 with a probability i.e. $p$-value $<0.01$ which indicates a rejection of the null hypothesis. 
Table 3. Regression Results

\begin{tabular}{|c|c|c|c|c|c|c|}
\hline Variables & Pooled OLS & $\begin{array}{l}\text { FE } \\
\text { CS }\end{array}$ & $\begin{array}{l}\text { RE } \\
\text { CS }\end{array}$ & $\begin{array}{c}\text { Pooled OLS } \\
\text { (Robust se) }\end{array}$ & $\begin{array}{c}\text { FE } \\
\text { (Robust se) }\end{array}$ & $\begin{array}{c}\text { RE } \\
\text { (Robust se) }\end{array}$ \\
\hline \multirow[t]{2}{*}{ IR } & 0.0262 & 0.0158 & 0.0262 & 0.0262 & 0.0158 & 0.0262 \\
\hline & $(0.0234)$ & $(0.0205)$ & $(0.0199)$ & $(0.0221)$ & $(0.018304)$ & $(0.022141)$ \\
\hline \multirow[t]{2}{*}{ IF } & 0.5862 & -0.0067 & 0.5862 & 0.5862 & -0.0067 & 0.5862 \\
\hline & $(0.3099) *$ & $(0.4175)$ & $(0.2629) * *$ & $(0.3069) *$ & $(0.500978)$ & $(0.306905) *$ \\
\hline \multirow[t]{2}{*}{ HPI } & 0.1939 & 0.1684 & 0.1939 & 0.1939 & 0.1684 & 0.1939 \\
\hline & $(0.0567) * * *$ & $(0.0516) * * *$ & $(0.0481) * * *$ & $(0.0574) * * *$ & $(0.0526) * * *$ & $(0.0574) * * *$ \\
\hline \multirow[t]{2}{*}{$\mathbf{U E}$} & 0.0107 & 0.0194 & 0.0107 & 0.0107 & 0.0194 & 0.0107 \\
\hline & $(0.0339)$ & $(0.0350)$ & $(0.0288)$ & $(0.0328)$ & $(0.034324)$ & $(0.032776)$ \\
\hline \multirow[t]{2}{*}{ HCE } & 0.0163 & 0.0209 & 0.0163 & 0.0163 & 0.0209 & 0.0163 \\
\hline & $(0.0029) * * *$ & $(0.0030) * * *$ & $(0.0025) * * *$ & $(0.0033) * * *$ & $(0.0041) * * *$ & $(0.0033) * * *$ \\
\hline \multirow[t]{2}{*}{ EG } & -0.0072 & -0.0075 & -0.0072 & -0.0072 & -0.0075 & -0.0072 \\
\hline & $(0.0027) * * *$ & $(0.0024) * * *$ & $(0.0023) * * *$ & $(0.0027) * * *$ & $(0.0022) * * *$ & $(0.0027) * * *$ \\
\hline \multirow[t]{2}{*}{ HDY } & -0.0838 & -0.0895 & -0.0838 & -0.0838 & -0.0895 & -0.0838 \\
\hline & $(0.0422) * *$ & $(0.0369) * *$ & $(0.0358) * *$ & $(0.0449) *$ & $(0.0395) * *$ & $(0.0449) *$ \\
\hline \multirow[t]{2}{*}{ CCI } & 0.2356 & 0.1080 & 0.2356 & 0.2356 & 0.1080 & 0.2356 \\
\hline & $(0.2189)$ & $(0.2017)$ & $(0.1857)$ & $(0.274411)$ & $(0.274894)$ & $(0.274411)$ \\
\hline \multirow[t]{2}{*}{ DUM_CRISIS } & -0.0158 & -0.0125 & -0.0158 & -0.0158 & -0.0125 & -0.0158 \\
\hline & $(0.0074) * *$ & $(0.0067) *$ & $(0.0062) * *$ & $(0.0072) * *$ & $(0.0069) *$ & $(0.0072) * *$ \\
\hline \multirow[t]{2}{*}{ Constant } & 0.0025 & 0.0063 & 0.0025 & 0.0025 & 0.0063 & 0.0025 \\
\hline & $(0.0089)$ & $(0.0129)$ & $(0.0076)$ & $(0.007495)$ & $(0.014836)$ & $(0.007495)$ \\
\hline Adjusted $\mathbf{R}^{2}$ & 0.4722 & 0.6201 & 0.4722 & & & \\
\hline F-statistic & $13.8222 * * *$ & $12.6968 * * *$ & $13.8222 * * *$ & & & \\
\hline F-tests & & $\begin{array}{l}6.1906 \\
(0.0000) * * *\end{array}$ & & & & \\
\hline $\begin{array}{l}\text { Wald } \\
\text { chi-square }\end{array}$ & & & $\begin{array}{l}124.40 \\
(0.0000)^{* * *}\end{array}$ & & & \\
\hline $\begin{array}{l}\text { Breusch Pagan } \\
\text { LM test }\end{array}$ & $\begin{array}{l}41.6481 \\
(0.0000) * * *\end{array}$ & & & & & \\
\hline Hausman test & & & $\begin{array}{l}0.0000 \\
(1.0000)\end{array}$ & & & \\
\hline $\begin{array}{l}\text { No. of } \\
\text { observations }\end{array}$ & 130 & 130 & 130 & & & \\
\hline
\end{tabular}

Parentheses show the standard error values, except for F-test, Wald chi square, BPLM and Hausman test which are $p$ values. $* * *$ Significant at the 0.01 level**Significant at the 0.05 level

\section{Discussion}

The regression results in Table 3 showed that the post financial crisis is statistically significant at the 5\% significance level and indicated a negative effect on household debt burden. There is evidence of sinking household debt taking place in advanced economies for the period post financial crisis. This deleveraging process is consistent with Tang and Upper (2010) and Buiter and Rahbeir (2012). The latter, in a study on selected advanced economies for the period of 1980 to 2010 found household credit growth likely to remain 
sharply below the growth rates post financial crisis. After what they had gone through during the subprime crisis in 2007, deleveraging, although at a slower pace, have triggered some high income households to lower their borrowings. In addition to this, stringent policies by central banks of each country have also curbed borrowings in more ways to control high household debt burden. For macroeconomic factors, HPI, HCE and HDY corroborates with the findings from past literatures.

\section{Conclusion}

The study found that post financial crisis has a significant negative effect on household debt burden. Therefore, the finding of this study adds to the existing literature on the effects of the global financial crisis on household debt. However, the deleveraging process that is taking place has been a slow process. Periods after 2014 actually saw household debt still on the rise for many countries and many are wary of the escalating household debt can bring these economies to the brink of another financial crisis. This study is limited to aggregated macroeconomic secondary data. It is suggested that future studies consider the household characteristics effects on household debt burden.

\section{Acknowledgements}

This research was financially supported by Universiti Teknologi MARA and a Malaysian government FRGS grant (RMI/FRGS 5/3 (37/2015).

\section{References}

Barnes, S., \& Young, G. (2003). The rise in US household debt : assessing its causes and sustainability. Working Paper Series, Bank of England, (206), 38.

Bloxham, P., \& Kent, C. (2009). Household indebtedness. Australian Economic Review, 42(3), 327-339.

Brown, M., Haughwout, A., Lee, D., \& Klaauw, W. van der K. (2010). The Financial Crisis at the Kitchen Table : Trends in Household Debt and Credit. Federal Reserve Bank of New York.

Brown, S., \& Taylor, K. (2008). Household debt and financial assets: evidence from Germany, Great Britain and the USA. Journal of the Royal Statistical Society Series A Statistics in Society, 171(3), 615-643.

Buiter, W., \& Rahbeir, E. (2012). Debt, Financial Crisis and Economic Growth. In Conference on Monetary Policy and the Challenge of Eeconomic Growth at the South Africa Reserve Bank, Pretoria, South Africa (pp. 1-2).

Crawford, A., \& Faruqui, U. (2012). What Explains Trends in Household Debt in Canada? Bank of Canada Review, 315.

Debelle, G. (2004). Household Debt and the Macroeconomy. SSRN eLibrary, (March), 51-64.

Dynan, K. E., \& Kohn, D. L. (2007). The Rise in U . S . Household Indebtedness : Causes and Consequences. Finance and Economics Discussion Series, (37).

Girouard, N., Kennedy, M., \& Andre, C. (2007). Has the Rise in Debt Made Households More Vulnerable? Economics Department Working Paper No. 535.

Harari, D. (2017). Household debt : statistics and impact on economy.

Jacobsen, D. H., \& Naug, B. E. (2004). What influences the growth of household debt? Economic Bulletin, 3(04), 103111.

Magri, S., \& Pico, R. (2012). Italian household debt after the 2008 crisis. Bank of Italy, Economic Research and International Relations Area, No. 134.

Mian, A. R., Sufi, A., \& Verner, E. (2015). Household Debt and Business Cycle Worldwide. National Bureau of Economic Research Working Paper No. 21581.

Tang, G., \& Upper, C. (2010). Debt reduction after the crises. BIS Quarterly Review, (September), 25-38.

Townsend, R. M., \& Ueda, K. (2006). Financial Deepening, Inequality, and Growth: A Model-Based Quantitative Evaluation 1. The Review of Economic Studies, 73(1), 251-293. 